\title{
Strategy of Sport Industry Development as Supporting Tourism in DIY
}

\author{
Ahmad Nasrulloh \\ Faculty of Sport Sciences \\ Universitas Negeri Yogyakarta \\ Yogyakarta, Indonesia \\ ahmadnasrulloh@uny.ac.id \\ Sigit Nugroho \\ Faculty of Sport Sciences \\ Universitas Negeri Yogyakarta \\ Yogyakarta, Indonesia \\ sigitnugroho@uny.ac.id
}

\author{
Sumaryanto \\ Faculty of Sport Sciences \\ Universitas Negeri Yogyakarta \\ Yogyakarta, Indonesia \\ sumaryanto@uny.ac.id \\ Sumarjo \\ Faculty of Sport Sciences \\ Universitas Negeri Yogyakarta \\ Yogyakarta, Indonesia \\ sumarjo@uny.ac.id
}

\begin{abstract}
Special Region of Yogyakarta (DIY) has very high chances between sport industry and tourism. There are many sports events held in DIY, both in national and international level. On the other hand, DIY has very rapid development in tourism sector. Therefore, the researchers intend to conduct research aiming at figuring out the strategy of sport industry development as supporting tourism in DIY. This research was descriptive qualitative research. The data collection technique was done by observation, interview, and documentation. Research subjects involved managers of tourist attractions, sports event organizers, and sport industry practitioners. The validity of data was done by the provision and triangulation of data through existing sources. Data analysis was performed by SWOT analysis method through reducing data, presenting data and verification or drawing the conclusion, along with the development of tourism in DIY, which is now experiencing an increase of special strategies, are needed to attract tourists. There needs to be structuring and regulation binding on all components of tourism management in DIY to realize an integrated service standard so as to provide comforts for both local and international tourists, optimizing the potential of tourism by cooperating with sport industry players to jointly synergize between the development of sport industry, especially sports events on increased tourism sector in DIY.
\end{abstract}

Keywords - sport industry, tourism

\section{INTRODUCTION}

Globalization has had a significant impact on the various dimensions of human life. There are three dimensions of the process of globalization, namely: Economic globalization, Political globalization, and Cultural globalization [1]. The universalization of the global value system that occurs in the cultural dimension has obscured the human values system of human life, especially in developing countries like Indonesia in the $21 \mathrm{st}$ century. Indonesian nation in this era of globalization is facing quite severe challenges; therefore the nation can also be said as a reflection of the value of life that occurs in society.

As a social and cultural phenomenon, sport cannot escape from the moral to the modern relation, mainly the dominance of the market. The acceptance of its sociological existence is guaranteed by its ability to adapt to the market, or vice versa and the market that will make it the target of its extension. That sport is a commodity good, where such commodity product becomes the target of market power [2].

Sports in this beloved country are still stagnant in achievement, one of which is due to lack of facilities and good education programs. In the field of sports industry development, Indonesia has had to do industrialization of sports as one way to overcome the problems. At the same time, the interest of western countries and the United States to invest in sports in Asia is the right moment to develop the industrialization of sports [3]. The sport industry is defined by Pitts, Fielding and Miller as "all production of goods, services, places, people, and thoughts that are offered to customers". Sport is not just big business. Exercise is one of the fastest growing industries, because it deals with aspects of the economy, the media and clothing to food and advertising, sport everywhere, coupled with an unfailing ringing of cash register machines [4]. Sport industry is one that creates added value by producing and providing sports related to equipment and services [5]. Sport marketing is the application of specific principles and marketing processes to sport products and to market non-profit sport products through association with sports.

Sport industry is sport business activity in the form of goods and / or of services. The sports industry can take the form of infrastructure and facilities produced, traded, and / or leased to the public. Communities conducting industrial goods and / or sports services should pay attention to the welfare of sports actors and the advancement of sport. It is stated that guidance and development of sports industry are implemented through mutually beneficial partnership to realize any sport activities that is independent and professional. The local government surely in developing the sports industry provides ease in the formation of centers of coaching and sports development [6].

In the national economy, the sport industry is a considerable base in supporting the transformation industry structure, from agrarian society to industrial society. There are several strengths, opportunities, weaknesses, and threats 
of sport industry in Indonesia, namely; (a) Strengths: Adequate product quality and reasonable price. (b.) Opportunities: Increased demand as sport awareness increases in the community. Export opportunities to emerging markets such as South Africa, Egypt and America. (c) Weaknesses: Limited capital and brand are still less well known, and (d) Threats: Products are easily made by other competitors and competition from local, regional and global brands.

Meanwhile, observing the sport industry business profile in Indonesia in its operational faces some problems such as [7]:

a. Capital issues.

The problem of capital of entrepreneurs in running their business has not been known and uses banking institutions. In addition, sports entrepreneurs (small) are difficult to obtain credit from private banks. As a result, sports industry entrepreneurs tend to rely on corporate financing from their own capital, or other sources such as family, relatives, and even loan sharks. Although they have enough collateral, they have no knowledge of where they should get easy and light capital. Another weakness in getting the capital is generally the sports industry is weak in preparing feasibility studies that can be accepted by the provider of capital.

b. Weak in gaining market opportunities and enlarging market share.

Generally, sport industry businesses acquire the market in passive ways. They rely on the power of the promotion of

Selling personnel, which is interpersonal communication. This promotion is chosen by the sports industry that is still small because the industry does not have the budget to conduct other promotions such as advertisements through television, radio or newspapers.

c. Limitations of technology use and mastery.

This is due to the weakness of human resources in absorbing science and technology. The weakness of human resources is also due to the level of education of workers in general, which is still low, then of course the (small) sport industry has experienced many limitations in utilizing technology.

d. The problem of product marketing strategy is one big obstacle for the small sports industry to enter the free market.

Often the marketing of small sport industry products has to go through the chain. The relatively long marketing and Product price setting is beyond the control of the sport industry entrepreneur. With conditions like this, problems facing the sport industry entrepreneurs is only to taste a relatively thin profit margin. Marketing difficulties can also be sourced from the level of keen competition, poor product quality, lack of supporting aspects (e.g. services of sports industry users), and lack of responsiveness of managers/ entrepreneurs to the market situation.

e. Weak in business networks and business cooperation.
Although the sports industry (which is still small) has limitations in networking and business cooperation, it does not seek to build networks and collaborate with the medium and large sports industries. The small sports industry does its own business activities and this will further weaken because of competition among the small sports industries themselves.

f. Weakness in the business mentality and entrepreneurship.

Generally, the sport industry that have the creativity and innovation, independence and spirit to move forward is still very small. It is still small to undergo many businesses that only rely on daily routines, without the touch of thought and development to always go ahead and increase.

There are three patterns related to the growth of the sport industry in Indonesia, namely: a) In Indonesia, there are potential sport actors and various scope or great sports dimensions. This is one of the success of the government's program to promote sports, b) There are three areas of the sector of arable fields, namely sport education, sport recreation, and sport achievement, and c) The magnitude of the growth opportunities in the sports industry. Of the three areas of arable fields above, the sport industry can penetrate in various market segments [2].

In addition to choosing and making various approaches to success in the sports business, it is also necessary to build a good communication with various parties. With communication able to solve the existence of a conflict so that will get the concept of higher quality solution, although there will be a change, but the change leads to a better and give impact to the common progress, especially in the sports industry. The sport industry has the following characteristics: a) persistent attention to business, b) being part or branch of business, and c) something that employs a lot of manpower and capital, which is a tangible activity of trade.

In the development of the sport industry in Indonesia, there needs to be re-orientation of the program, some of which are as follows [8]:

a. Development of Sport Culture

Sports culture is the main foundation in the development of national sports. Sport culture is the attitude and habits of people to enjoy exercising and make sports ad healthy lifestyle. The development of this sports culture can be started from the scope of individuals and families by giving an appreciation of the meaning and benefits of sports for improving health and quality of life.

b. Regional and International Sport Competition

National sport achievements continue to decline at regional and international levels. This condition is due to the weak competitiveness of national sports compared to other countries. The rise of new powers in sports, both at the ASEAN, Asia, and the world, has a profound influence on the position of Indonesian sports forces. The development of sport in Thailand, Malaysia, China, and several countries in the Soviet Union are the 
forces that influence the decision of sport coaching in general in Indonesia.

c. National Sport Management

An integrative approach in establishing policies that enable coaching and development of national sports in a harmonious, integrated and long-term manner that is supported by a funding system with principles of sufficiency and sustainability is very important in supporting the success of sports development.

d. Sport Infrastructure and Application of Research and Science and Technology

Application of science and technology in sport coaching both to improve the quality of the teachinglearning process and training is a must. Process quality ensures the achievement of learning outcomes and targeted sports performance. It is difficult to imagine the achievement of learning outcomes or high achievement without the use of science and technology. The availability of science and technology support including laboratory facilities for sports teaching and training is needed in an effort to improve achievement. For example, the success of sports achievements in other countries such as Australia and China is due to this problem.

e. Program Synchronization between; Government, Society, and Private

Sports policies taken by the Government are very necessary and are still dominant for the smooth process in the field, such as sports financing subsidies. The community and the private sector as implementers in the field will protect behind the policies decided by the government, so that in the implementation, the community or the private sector can work calmly and safely. Third-party market or markets, are obliged to popularize sports in the community, so that the sports sector is not only a non-profit sector but also a profit and can be sold to the public.

f. The Role of Banking in the Development of the Sport Industry

In terms of coaching, banks actually play a role, some of which have their own sports clubs and actively participate in competitions and recruit talented athletes. It is desirable for banks not only to act as sponsors of events or a club which is usually intended but also as a promotional effort, but can enter again deeper.

The sports industry can be divided into two, that is the sport itself and its supporters. Sports can be in the form of an event or branch, while the supporters are quite a lot. Some of the supporting factors include mass media, both electronic and print media, sports equipment, advertising, arena rental services, trinkets or merchandise, and many more. The number of banks operating in this country at this time is around 120. If each one wants to enter and carry out his/ her role according to ability, we are optimistic that the world of national sports will be excited again.

The development of the sport industry, especially sports tourism, needs to get serious attention in order to be able to create a society that is advanced and more transformative, that is, both structurally and culturally [7]. Tourism prospects in the global market in the future are getting better. The world tourism industry is expected to continue to grow to $4.3 \%$ annually until 2020 . The WTO also predicts that in $2010,1.046$ billion people will make tourist visits and increase by 1.602 billion in the year 2020, including 231 million people (in 2010) and 438 million people (in 2020), who will travel in the East Asia and Pacific region [9]. About $8 \%$ of the export of goods and services comes from the tourism sector. Tourism has also become the largest contributor to international trade from the service sector $(37 \%)$, becoming the main source of foreign exchange with $38 \%$ in the world. Meanwhile, in Southeast Asia, the tourism industry contributes 10 to $12 \%$ of GDP and absorbs 7 to $8 \%$ of the workforce [10].

Tourism is one industry that has an important role in economic, social, cultural and environmental development. Tourism development that is planned and managed in a sustainable manner based on the community will be able to contribute to foreign exchange revenues and create jobs. In addition, tourism development can also create income that can be used to protect and preserve culture and the environment and directly touch local communities/tourist destinations.

In addition, there is an opportunity to synergize the culture industry and the sport industry which has the potential to become tourist objects and attractions. The proximity between the cultural industry and the sport industry with tourism has been recognized by many countries. In some countries, unique and exotic cultural industries are attracting tourists. Likewise, with the world championships in various sports, such as the Olympics and the Football World Cup, it can invite millions of foreign fans and tourists.

As a product of the tourism industry, the culture and sport industry needs further processing to attract tourists as consumers. The processing of these two products in synergy and planning, will have positive impact on tourism development and ultimately will be able to encourage increased foreign exchange revenue from the tourism sector in the form of event-based tourism, whether cultural events, sports events or combination of both.

Tourism development referred to in this research is focused on event- based tourism. Event-based tourism that is studied is cultural event and sporting event that has great potential as an attraction and as a means of promoting the organizer area. People who come to watch an event can go on a tour while the people who watch the event on television become interested in visiting the area. The organization of the event is also able to provide benefits to the region and the community as well as small and medium businesses around the organization.

A synergized cultural and sport activity will be able to bring in foreign and local tourists. However, in Indonesia, the use of arts and culture to market sport events has not been widely used until now by sports marketing experts, and vice versa. Meanwhile in Australia, in organizing the 
Sydney Olympics, marketing programs and organizing sporting events, had been synergized with art and cultural activity programs, mainly by making art and culture major components required in organizing sporting events.

The tourism event is an integral and main part of tourism development and marketing strategies. Tourism events can be used to describe social phenomena and this can be interpreted as "systematic development, planning, marketing, and being flashback of past history". The purpose of tourism event can be; (a) To create an image that is beneficial for tourist destinations in the destination or country, (b) To expand the cultural information and local traditions, (c) To spread tourism demands more evenly in an area, and (d) To attract foreign and domestic visitors.

Statistics shows that, for example; in the sector of exhibition, event segments can increase strong international presence between $15 \%$ and $20 \%$. This is very beneficial to other tourism sectors such as hospitality and transportation. Many official delegations from various countries then added other activities such as business trips to mini holidays. Events can be the most common channels where visitors fulfill their desire to taste local food and traditions, participate in games, or be entertained. Local and regional events can have the added advantage of keeping the domestic tourism market active [11]. Even tourists or visitors can be defined as those who travel far from home for business, pleasure, personal affairs or other purposes (except for commuting to work) and who stay at an event destination [12].

Olympic Games are one form of synergy in the cultural and sport industries that can attract tourists; it is not surprising that the Olympic Games are contested by many countries. The event is a very close combination of sports, festivals, religious ceremonies (rituals), and opening / closing ceremonies. As in the 44th regulation of the Olympic Charter, it states that: (1) the organizing committee (OC) for the Olympic Games must develop cultural event programs that are submitted to the International Olympic Committee (IOC) to get approval; and (2) the programs must promote harmonious relationships and mutual understanding and friendship among participants and visitors of the Olympic Games.

Whereas in the following explanation, it is stated that cultural programs must include: (1) Cultural events that must be organized in the Olympic region and lead to universality and differences in human culture; (2) Other events that have the same objectives held in city hosts with a number of seats that have been reserved for free for participants who are accredited by the IOC; and (3) Cultural Programs must be carried out during the Olympic Games event.

Referring to the experience of other countries in organizing event- based tourism, there are several examples that have been developed. For example, to develop a Canadian government sporting event every year, they hold Sport Event Congress which is a meeting of representatives of sports actors, sports organization, event right holders, convention, and visitors' bureaus, economic development institution, supporting industry, sponsor organization/ company and event management companies both national and international. The forum becomes a means of marketing sport events where the right holder of the event has the opportunity to offer their event to the city representative to host.

Australia establishes national sport tourism development strategy in the form of the National Action Plan for Tourism which had been proclaimed since 1998. In Australia, every sporting event is planned so well that it can bring tourists both foreign and local. Recognizing this and taking the experience of Sydney Olympics, the marketing program and the organization of sports events are synergized with the arts and culture programs, by making art and culture as the main component required in organizing sports event.

In Scotland, the event has significant potential in supporting tourism development. Therefore, the Scottish Government has great commitment to develop the event that is reflected by the launch of the Major National Event of 'Competing on an International Stage' by the Scottish Executive in 2003. The Government has the vision to make Scotland a leading event in the world in 2015, namely: (1) making the event an "icon" or hallmark event; (2) Events that can be developed into world events; (3) International events held in Scotland without investing in Infrastructure, (4) Annual or mid-year event that can be Developed in specific areas. This event can be sport, history, art and culture or festival. In order to disseminate the national strategy, the Scottish Executive and Visit Scotland created the Even Scotland Partnership with public institutions, event organizers, media, and private sectors. The institute provides financial support and consultation to ensure, create, and develop international leading cultural and sporting events in Scotland.

The country of Indonesia is rich in cultural industries and potential sport industries to support tourism. This cultural resource support is seen by the abundance of national culture and diversity. All cultural currents throughout the three millennia are flowing into the archipelago from India, China, the Middle East and Europe. All of these world cultures are represented in certain places, such as in Bali that is Hindu; Chinese settlements in Jakarta, Semarang and Surabaya; Muslim centers in Aceh, Makasar and the Padang plateau; in Minahasa and Ambon regions which are Calvinists; and the Flores areas that are Catholic. These show that Indonesia is a rich country in activities and cultural expressions that are very unique and exotic which have potential to be developed. Based on the description above, it shows that the sports industry is familiar in the world of Indonesian tourism. However, the development of synergy between the two fields is not yet optimal. Therefore, the researchers are interested in conducting research on the development strategy of the sport industry as the support for tourism in DIY. In order to improve the performance of national tourism built a joint commitment to develop the sport industry in synergy. Forms of support are needed at all levels of actors, 
including government, private sectors, and the community at the policy and operational levels at the central and regional levels.

\section{ReSEARCh Methodology}

This study used qualitative approach. Qualitative research is one that intends to understand the phenomenon of what is experienced by subjects of research holistically by way of describing into words and language in accordance with the actual situation in the field [13]. The research method used was descriptive qualitative research method. It is a form of research intended to describe the phenomena that exist, both natural and manmade phenomena. The phenomenon can be the form, activity, characteristics, changes, relationships, similarities, and differences between phenomenal with one. With the use of qualitative methods, the data obtained will be more complete, more in-depth, credible, and meaningful so that research objectives can be achieved [14]. This research used data analysis technique model by Miles and Huberman. They argue the activity in qualitative data analysis conducted is interactive and lasted continuously until completion, so the data were saturated. Data analysis was by using SWOT analysis method by reducing data, presenting data, verification or drawing the conclusion.

\section{DISCUSSION}

The development of tourism sector in Special Region of Yogyakarta (DIY) currently tends to experience a very significant increase. This is shown by the growing and increasing tourist destinations in DIY, so that the tourism sector will be able to help drive the economy of society. DIY Jargon, as a city of students and cultural city, becomes its own magnet against the tourists to come to DIY. The strength of tourism in DIY lies in local wisdom and culture of the society and is supported by human resources who already have an awareness of the positive outlook of the tourism sector. Creative human resources also become its own strength to the development of the tourism sector. In addition, there are still many tourism potentials that can still be worked to the maximum to support the populist economy. Various supporting facilities are also available in DIY such as infrastructure, good accommodation and accessibility so as to boost the tourism sector.

The development of the tourism sector in the form of tourist villages and interesting new tourist destinations in every district in Yogyakarta has tremendous potential. The existence of cultural heritage buildings, Sultan Palace, and relics of historical objects that exist in DIY is also a special attraction for tourists. Natural potential in the form of mountains and oceans, strategic geographical location makes DIY worthy of being a tourist destination. Some of the tourism potentials that can still be developed in DIY are water tourism (along the south coast, reservoirs, rivers), nature tourism (in the hills, Merapi Mountain), cultural diversity, culinary, technology, educational and historical tours, promoting local wisdom and culture, sport tourism and water sports. By looking at tourism potentials and existing strength of the tourism sector in Yogyakarta, it will be able to compete with tourism in other areas.

Along with the development of tourism in DIY, which is experiencing an increase, there are still some shortcomings that must be addressed. Although it is difficult to show the weakness of the tourism sector in DIY, there are still some things that become complaints from the traveler community who often visit various tourist destinations in DIY. Management of some tourist attraction is not optimal but still the attraction of tourists is still lacking. Promotion of tourism destinations in DIY also need to be improved, either through print, electronic and social mediums. In terms of services, some attractions still need to be improved. Routine maintenance must also be done by the manager of the tour so that the tourist attraction can be neat and clean so that every tourist can be impressed and will re- visit again in the future. There are some objects complained about the arrangement and management of parking that has not been centralized because there are some unscrupulous people who make their own parking rates where the tariff is much more expensive than the tariffs that have been determined by the provincial government of DIY, thus causing tourists to feel burdened and reduce comfort when traveling. Therefore, there is a need for structuring and regulation binding on all components of tourism management in DIY to realize an integrated service standard so as to provide comfort for the tourists both local and international.

There are several potentials that can be developed to boost the tourism sector in DIY. The culinary tour, tourist village, beach tourism, natural attractions and new tourist attraction are the tourism potential that can be developed at this time. There are some supporters who are able to leverage the tourism sector in DIY for good accessibility between tourist attractions with one another. The distance is relatively short so it allows tourists to visit tourist destinations. In addition, the enthusiasm of tourists to visit the destinations in DIY helps promote it through social media.

Another potential that can still be developed to increase tourist visits to tourist destinations in DIY is with the sports industry. The development of the sport industry that exist today is actually quite good. It is shown by the existence of various sports events both nationally and internationally held in DIY such as BWF Word Junior, ASEAN Futsal Club Championship, Indonesia Profutsal League, Asia Futsal Competition, ISL, IBL, Proliga volley, POMNAS (National Student Sport Week) and so forth. More and more sports events should be able to attract supporters, athletes, and coaches, official, game equipment and sports lovers to visit the sights. In addition there are several sports industries that can be developed and juxtaposed with tourism such as rafting, outbound, bike tour, fly kite, archery, bike cruise tours, rowing, marathon in tourist areas, extreme sports, sport games on the beach and so forth.

Actually, with the growing development of sports industry in DIY, it will be able to provide its own carrying capacity for the tourism sector. This is shown when there is a sport event, athletes and sports lovers who come to DIY 
will take the time to visit the nearby attractions with the sport event, so it will be a potential promotion either through word to word or social media from his personal account. However, in reality the current development of sports industry in Yogyakarta has not been able to contribute significantly to the tourism sector in DIY. This is because there has not been a synergistic management pattern between sports industry players with related agencies and tourism object managers. In addition, there is still lack of coordination with related parties and lack of human resources who have the willingness and ability in the sport industry development in supporting tourism in DIY. Therefore, a special strategy is needed to be able to synergize between the developments of sports industry, especially sports events to increase tourism sector in DIY.

Along with the development of tourism in DIY, there are still some complaints that can threaten the comfort of tourists while visiting tourist destinations in DIY. Frequent occurrence of natural disasters such as erupting volcanoes, whirlwinds, earthquakes, high waves can cause tourists inconvenience during the visit, even when a natural disaster such as a mountain erupts. Some attractions must be closed to anticipate the safety of tourists. However, natural disasters that occur when packaged properly, will turn into an attractive natural tourism potential because it has its own challenges such as lava tour.

Issues that are developing at this time is criminality that threatens the convenience of tourists is 'klitih'. The frequent 'klitih' criminal issue in DIY is a serious threat to the DIY government. 'Klitih' is the activity of a group of irresponsible people who deliberately attack someone while traveling with a sharp weapon or other blunt object, so it can hurt even to death. Therefore, in order to maintain the comfort of the tourists while visiting the tourist attractions in DIY required special strategy to dismiss the issue 'klitih' is. Another issue that is happening today is the presence of a group of terrorist network people who have entered the DIY. This terrorist issue can be a threat for tourists to visit the DIY especially foreign tourists. Therefore, the DIY government must take preventive steps in cooperation with the TNI (Indonesian Army) and Police to immediately solve the problem of criminality and terrorists. If the level of security in DIY region is guaranteed, it will increase the convenience of tourists in visiting tourist destinations that exist throughout DIY.

From the SWOT analysis that has been described above, there are still some things that need to be developed to boost the tourism sector in DIY. There are several opportunities for tourism destination development that can be developed in DIY. One of the opportunities that has not been optimal is from the sport industry side, where the current development of the sports industry, especially about the sporting event, has been more and more in DIY along with the development and utilization of existing sports value. The development trend of the sport industry in the field of sports events has increased significantly, so it can be said that the more sports events held in DIY will be a magnet for sports lovers to come to DIY. The phenomenon should be captured positively by the managers of tourist destinations in DIY to be able to promote to sports lovers who come to DIY in order to enjoy various tourist attractions in DIY to fill his spare time while watching sports games. Therefore it is necessary to have a special strategy to be able to synergize between the development of sport and tourism industry in DIY.

One of sport industry development strategies to support tourism in DIY is to multiply even a largescale sports events both national and international level by packing the tourist sport-based event. Where at every sport event held in DIY, it is necessary to cooperate with tourism object to offer tour packages on the side lines of sports event. In addition, it is necessary to maximize cooperation with the provision of services field tours and travel to be able to offer tourist attractions that can be visited. Another strategy is the need for cooperation between relevant agencies, tourism object managers, sports event providers and sports value provider to synergize together promote tourism in DIY. Mobilize and embrace human resources, community and tourism community to jointly encourage the development of tourism in DIY.

It needs special assistance to human resources in order to be able to develop the sport industry that is packaged by combining the tourism sector. In the sports industry, organizing sports events held at tourist attractions such as paragliding done at Depok Beach and surrounding areas, marathon around the temple, rock climbing beach, fun bike tours, downhill bike, extreme sports, outbound and nature roaming may help so that events which are held in the tourist attraction will be more attractive to tourists who will enjoy the panorama of the sites as well as follow or watch sports events held. In addition, special strategies are needed to promote the sports industry's synergy with tourism simultaneously through print, electronic and social mediums so that it can be accessed easily by people around the world.

\section{CONCLUSION}

Along with the development of tourism in DIY experiencing an increase of special strategies are needed to attract tourists. Optimizing the management of several tourist objects thus increases tourist interests. Promotion of tourism destinations in DIY also needs to be improved. In terms of services, some attractions still need to be improved. There is need to be structuring and regulating binding on all components of tourism management in DIY to realize an integrated service standard so as to provide comfort for the tourists both local and international. Optimizing the potential of tourism by cooperating with sport industry players to jointly synergize between the development of sports industry, especially sport events to increase tourism sector in DIY. Sport industry development strategy to support tourism in DIY is to multiply even large-scale sport events both national and international levels by packing the tourist sport-based event. In addition, it is necessary to maximize cooperation with the provision of services field tours and travel to be able to offer tourist attractions that can be visited. Another strategy is the need 
for cooperation between relevant agencies, tourism object managers, sports event providers and sports value provider is to synergize together promote tourism in DIY. Mobilizing and embracing human resources, community, and tourism community are to jointly encourage the development of tourism in DIY. It needs special assistance to human resources in order to be able to develop the sports industry that is packaged by combining the tourism sector. In addition, special strategies are needed to promote the sports industry's synergy with tourism simultaneously through print, electronic, and social mediums so that it can be accessed easily by people around the world

\section{REFERENCES}

[1] K Buseri, "Nilai-nilai ilahiah remaja pelajar, Telaah phenomenologis dan strategi pendidikannya". Yogyakarta: UII Pres. 2014.

[2] F. Sriwahyuniati, "Membuka peluang bisnis olahraga kebugaran (fitness dan senam) dalam mengembangkan program industri olahraga melalui program kuliah kewirausahaan", 2014. Available from: http://staff.uny.ac.id/sites/default/files/131568302

[3] Ibnu, "Visi, misi, sasaran dan program kadin olahraga nasional", 2012. Avaiable from: http://sport.ghiboo.com/visi-misi-sasaran-danprogram-kadin-untuk-olahraga-nasional

[4] Harsuki, "Peluang industri olahraga di tingkat global. Materi workshop pengembangan manajemen indusri olahraga di Malang", 2011.

[5] Nuryadi, "Industri olahraga", 2010. Available from: (http://ebookbrowse.com/gdoc.php?id=363998

[6] Undang Undang No 3, "Sistem Keolahragaan Nasional: Kementrian Negara Pemuda dan Olahraga Republik Indonesia”, 2005.

[7] F. Mulyaningsih, "Pemberdayaan industri olahraga dalam menghadapi pasar bebas", 2011. Available from: (http://staff.uny.ac.id/sites/default/files/131808341/ProceedingSEMN AS

[8] P. Bambang, "Pengembangan pembangunan industri keolahragaan berdasarkan pendekatan pengaturan manajemen pengelolaan kegiatan olahraga. Jurnal Media Ilmu Keolahragaan Indonesia", 2012, Volume 2. Edisi 2. ISSN: 2088-6802. 2012.

[9] WTO, Tourism: 2020 Vision, 2000.

[10] J Naibitt, "Global Paradox". William Morrow and Company, nc. 1994.

[11] D. Getz, "Special events. In Managing Tourism", ed S Mede-lik. PP. 67-123. Oxford: Butterworth-Heinemann, 1991.

[12] B. A. Masberg, "Defining the thourist is it possible?", Journal od Travel Research, Vol. 37, pp. 67-70, Agugust 1998.

[13] L. J. Maleong, "Metode penelitian kualitatif”. Bandung: PT Remaja Rosdakarya, 2004.

[14] Sugiyono. "Metode penelitian kuantitatif, kualitatif dan R \& D". Bandung: Alfabeta, 2009. 